This item was submitted to Loughborough's Research Repository by the author.

Items in Figshare are protected by copyright, with all rights reserved, unless otherwise indicated.

\title{
Fiscal sustainability in the euro-zone: is there a role for euro-bonds?
}

PLEASE CITE THE PUBLISHED VERSION

http://dx.doi.org/10.1007/s11293-014-9416-4

\section{PUBLISHER}

Springer Verlag @ International Atlantic Economic Society

\section{VERSION}

AM (Accepted Manuscript)

\section{PUBLISHER STATEMENT}

This work is made available according to the conditions of the Creative Commons Attribution-NonCommercialNoDerivatives 4.0 International (CC BY-NC-ND 4.0) licence. Full details of this licence are available at: https://creativecommons.org/licenses/by-nc-nd/4.0/

\section{LICENCE}

CC BY-NC-ND 4.0

\section{REPOSITORY RECORD}

Ahmad, A.H., and Su-ling Fanelli. 2019. "Fiscal Sustainability in the Euro-zone: Is There a Role for Eurobonds?". figshare. https://hdl.handle.net/2134/16841. 


\title{
Fiscal Sustainability in the Euro-Zone: Is There A Role for Euro-Bonds? ${ }^{1}$
}

\author{
A. H. Ahmad ${ }^{2}$ \\ and \\ Su-ling Fanelli ${ }^{3}$
}

\begin{abstract}
This paper assesses the fiscal sustainability of ten Eurozone member countries at a national and aggregate level. It is carried out in light of the relevant literature on monetary unions and the framework of the European Monetary Union vis-à-vis the current sovereign debt crisis. The impact of Eurobonds, which is considered as a viable solution, on fiscal sustainability was empirically tested. The results indicate that only three countries appear to be structurally sustainable whereas the majority of the countries are only sustainable in the short-run and two countries are structurally unsustainable. However, the sustainability of the Eurozone is greatly improved when the Eurobonds are used.
\end{abstract}

Key Words: Fiscal sustainability, Eurozone, Eurobonds

JEL Classification: E620, E650

\footnotetext{
${ }^{1} \mathrm{We}$ are very grateful for the referee's as well as the editor's helpful and constructive comments. We also thankfully acknowledge invaluable suggestions that we received from Bruce Morley.

${ }^{2}$ Corresponding author. School of Business \& Economics, Loughborough University, Leicestershire, LE11 3TU, A.H.Ahmad@lboro.ac.uk, Tel: +44 (0)1509 222719.

${ }^{3}$ Department of Economics, University of Bath, Claverton Down, Bath, BA2 7AY.
} 


\section{Introduction}

The financial crisis that started in the mid -2007 , affected most of the Eurozone countries. This led to an increase in budget deficits and consequently triggered a sovereign debt crisis. The sovereign debt crisis started in Greece in 2009, then spread and affected many Euro countries. The contagion from the peripheral countries of Ireland and Portugal, has affected some of the core Euro countries such as Italy. In addition, the exposure of European banks and financial institutions to sovereign debt has caused detrimental market instability that has compelled the governments of these countries to pass austerity measures aimed at addressing the budget deficits. In order to ensure a definite end to the crisis, avoid a default and a threat to the Euro, a decisive and effective action that will lead to the fiscal sustainability of these countries needs to be taken. Fiscal sustainability ${ }^{4}$ is a general concern to both policy makers and the business community as an unsustainable fiscal stance will lead to the governments' inability to alleviate their debt ratios. If the situation persists, it could lead to a state of insolvency.

Empirical work on the fiscal sustainability of individual Euro countries has produced contradictory results. For example, Papadopoulos and Sidiropoulos (1999), De Castro and Hernandez de Cos (2002), Trachanas \& Katrakilidis (2013), Arghyron and Luintel (2007), Bajo-Rubio et al. (2009), and Legrenzi and Milas (2012) have found evidence that supports the existence of fiscal sustainability in countries that include Greece, Italy, and Spain. Afonso (2005) and Corsetti and Roubini (1991), on the other hand, reported results that indicate nonsustainability of the fiscal position of the countries. In their recent work, Benassey-Quere and

\footnotetext{
${ }^{4}$ There is little consensus on what fiscal sustainability means. For example, see Afonso (2005), Arestis, et al. (2002) and Arghyrou and Luintel, (2007) for detail discussion on the concept. However, for clarity, fiscal sustainability, as used in this paper, refers to a government's capacity in executing a set of fiscal policies whilst remaining solvent. Therefore, a country is considered to be fiscally sustainable when the ratio of its public debt to GDP is stationary and consistent with demand for government securities.
} 
Roussellet (2013) have shown that the presence of systemic banking risks can significantly affect a country's fiscal sustainability.

Fiscal discipline within a monetary union is fundamental because if one country diverges, it will affect other members of the union. This, therefore, calls for an explicit fiscal discipline criteria and fiscal co-ordination mechanism. If a country is fiscally irresponsible, it will threaten the interests of the entire union since the other member-countries will be required to bear the costs of financing its debt. Consequently, a country that is in a monetary union will no longer be able to monetise its debt, thereby the imposition of fiscal discipline is essential for the survival of the union. It is to this end that fiscal consolidation of the Euro countries is advocated. (Arestis et al, 2002).

This paper extends the existing literature on the fiscal sustainability of the Eurozone by empirically testing the sustainability of the Eurozone as a whole and testing the impact of Eurobonds, which has been largely overlooked by the existing literature. In addition, the impact of Eurobonds was analysed within the individual country context. The results indicate that only three core Euro countries; Germany, Finland and Austria exhibit characteristics of medium- and short-run fiscal sustainability. The Netherlands, France, Spain, Portugal and Ireland are found to be weakly sustainable. ${ }^{5}$ This means that without changes in fiscal and structural policies, these countries' positions will deteriorate. Italy and Belgium, on the other hand, appear to be structurally unsustainable due to their large accumulated stock of debt. Drastic actions aimed at decreasing the stock of debt of these countries are required in the short-run whilst pursuing economic reforms for the long-run sustainability. The situation is more urgent in the case of Italy than Belgium. Generally, the results obtained from estimates that included the Eurobonds have greatly improved the fiscal sustainability of these countries,

\footnotetext{
${ }^{5}$ These countries, except Ireland, are among the countries that the European Commission recommended to the Council to extend deadlines for correcting their excessive deficit. See European Commission - MEMO/13/463 29/05/2013 available here: http://europa.eu/rapid/press-release_MEMO-13-463_en.htm.
} 
but the results are sensitive to the rate of interest used. ${ }^{6}$ The empirical evidence, therefore, backs the view that consolidating national debts of the Euro countries will help in addressing the fiscal sustainability issue among the members.

The rest of the paper is structured as follows. The next section discusses the methodology used in the empirical analysis and followed by the analysis of the empirical results. Based on the findings of the paper, some policy implications and conclusions as well as some limitations of the paper are discussed in the last section.

\section{Methodology}

The paper uses the model proposed by Quintos (1995), which allows for tests for weak and strong fiscal sustainability. The methodology extends the framework proposed by Hakkio and Rush (1991) and Hamilton and Flavin (1986). The model assumes that a country's fiscal sustainability holds if the inter-temporal budget balance of the country is satisfied. That is if the government's current market value of its debt is equal to its future present value. The one period budget constraint is derived by Hakkio and Rushs (1991), which can be represented as:

$$
\Delta B_{t}=G_{t}^{r}-R_{t}
$$

where $B_{t}$ is the stock of marketable debt, $G_{t}^{r}$ government expenditure inclusive of interest payments on the previous period's stock of debt and $R_{t}$ is the government tax revenue. With forward substitutions one will obtain the inter-temporal budget constraint, which is given as:

$$
G_{t}^{r}-R_{t}=\sum_{j=0}^{\infty} \gamma^{j-1}\left(\Delta R_{t+j}-\Delta E_{t+j}\right)+\lim _{j \rightarrow \infty} \gamma^{j+1} \Delta B_{t+j}
$$

\footnotetext{
${ }^{6}$ There are two options; either to use the national interest rates or German interest rates. We have used both in this paper. See Section 3 for details.
} 
where $E_{t}=G_{t}+\left(r_{t}-r\right) B_{t-1}$ and represents government expenditure inclusive of interest payments on past stock of debt where the interest rates have a mean equal to zero (Quintos, 1995). The government deficit or surplus is equal to tax revenue minus government expenditure inclusive of interest rate payments on the accumulated stock of government debt, but it is assumed that in the future the stock of debt will converge to zero. For the intertemporal budget balance to be fulfilled, the limit imposed on the model in equation (2) needs to be satisfied:

$$
E_{t} \lim _{j \rightarrow \infty} \gamma^{j+1} \Delta B_{t+j}=0
$$

However, in order to test this limit it is possible to test for the stationarity of $G_{t}^{r}-R_{t}$ and impose a co-integrating vector of $(1,-1)$ if both series are integrated of order one. That is, they are I(1) in levels. Nevertheless, one could also test for co-integration or otherwise in the model in equation (4). One can also test whether or not the $b$ coefficient of government expenditure in the model is equal to unity:

$$
R_{t}=\mu+b G_{t}^{r}+\epsilon_{t}
$$

By using a co-integrating relationship, one can distinguish whether a country is sustainable in the weak or strong form, depending on the value of the coefficient $b$ and existence of cointegration. Hakkio and Rush (1991) argue that for a country to satisfy the strict budget deficit sustainability, there has to be a co-integrating relationship and the coefficient $b$ of government expenditure inclusive of interest payments in equation (4) should be $0<b<1$.

\section{Fiscal sustainability at a National level: Unit roots, Diagnostic and Co- integration Tests}

To test for fiscal sustainability at a national level, time series data for all the countries covered for the period studied are used. Government expenditure inclusive of interest rate payments $\left(G_{t}^{r}\right)$ and budget surpluses are estimated as follows: 


$$
\begin{gathered}
G_{t}^{r}=G_{t}+r_{t} B_{t-1} \\
G_{t}^{r}-R_{t}=\text { budget surplus }
\end{gathered}
$$

where $r_{t}$ is the interest rate on long term government bond yields at time $t$ for each country. The following variables will be checked for unit roots for all the countries: $G_{t}^{r}, G_{t}^{r}-R_{t}, R_{t}$, $B_{t}, r_{t}$ and $G_{t}$. Subsequently, co-integration tests are carried out. The co-integrating relationship test takes the form specified in equation (4). A Wald coefficient test will be performed to determine the value of the coefficient $b$. The Wald test has a $\chi^{2}$ distribution and is similar to the F-test of joint significance with a null hypothesis, $H_{o}: b=1$ against the alternative, $H_{1}: b \neq 1$. If one fails to reject the null then model suggest that the country is fiscally unsustainable.

\section{Fiscal Sustainability of the Eurozone at an Aggregate Level}

In order to test for the fiscal sustainability of the Eurozone at an aggregate level, an integrated time series are used where panel cointegration tests are carried out. Panel data is believed to be capable of producing more reliable estimates since the tests have greater predictability power, as lack of data is no longer an issue (Maddala and Kim, 1999: 137). Furthermore, as argued by Banjeree, (1999), when estimating the long-run relationship between two variables, the co-integrating relationship can be spurious when using time series data but this is not the case when using panel data. This is because due to the fact that the noise in the time series is mitigated by the cross-section dimension (Phillips and Moon, 1999). The panel co-integration tests of the Kao and Pedroni were used thereafter to test for the countries' fiscal sustainability at the aggregate level. The tests are based on:

$$
\begin{aligned}
& y_{i t}=x^{\prime}{ }_{i t} \beta+z^{\prime}{ }_{i t} \gamma+e_{i t} \\
& \hat{e}_{i t}=\rho \hat{e}_{i t-1}+v_{i t}
\end{aligned}
$$


with a null $\rho=1$ in equation (8) against the alternative. The test allows for increased heterogeneity within the panel data, which makes it more applicable to the Euro countries that are generally heterogeneous (Hsiao, 2003: 216). The test has a null of $H_{0}$ : co-integration against the alternative.

Impact of Eurobonds on Fiscally Sustainability of the Euro-Zone at Individual and at the Aggregate Levels

In order to examine the impact of the Eurobonds on the Eurozone fiscal behaviour, a historical dataset from 1980 to 2010 is used. However, it is possible to estimate the impacts of Eurobonds by hypothetically creating "blue bonds" and "red debt" and re-examine fiscal sustainability of these countries at both the national and aggregate levels ${ }^{7}$. If a country is fiscally sustainable its government expenditure, inclusive of interest payments, and tax revenue would converge. However, Eurobonds would alter the nature and composition of interest payments on government bond yields. Hence, the model in equations (4) and (5) are modified to take into account the effects of the Eurobonds. Since the rate of interest used is crucial, different estimations are carried out based on equations (4) and (5) using different rates of interest. The modified model is given as:

$$
G_{t}^{r *}=G_{t}+r_{b t} \text { Blue Bonds }{ }_{t}+r_{\text {rit }} \text { Red Debt } t_{t-1}
$$

where $r_{b t}$ is the rate of interest on "blue bonds" and $r_{r i t}$ is the interest rates on "red debt", which are different for each country. Considering that in the original model of equation (4), $G_{t}^{r}$ included interest payments on the stock of debt in the previous period, it is assumed that the stock of debt considered for "blue bonds" will not change, if a country has a debt ratio

\footnotetext{
7"Blue bond" refers to Eurobonds that are jointly issued by Euro countries up to $60 \%$ of their GDP, which will be repaid under all circumstances. They will be fully guaranteed and to enjoy super-safe AAA rating. Eurobonds issued above $60 \%$ of GDP would have to be issued in the national bond markets and labelled "red bonds". This is a junior tranche that will face a higher risk premium. For full discussions on the proposed Eurobonds, see Delpla, Jaques; von Weizsäcker, Jakob (2011) and De Grauwe, (2012).
} 
higher than $60 \%$ of its GDP. However, the excess debt, classified as "red debt" would change from year to year. For instance, Italy's debt exceeded 60\% of its GDP in 1983, thereafter only "red debt" changed.

\section{Eurobonds I}

The test of fiscal sustainability of the countries using the German interest rates is given as:

$$
G_{t}^{r *}=G_{t}+r_{b t} \text { Blue Bonds }{ }_{t}+r_{\text {rit }} \text { Red Debt } t_{t-1}
$$

where $r_{b t}$ denotes German historical interest rates and $r_{\text {rit }}$ represents the domestic interest rate of the country, for example for Italy, $r_{\text {rit }}$ is Italian interest rates. Using historical interest rate data it is equivalent to estimating the impact of Eurobonds on fiscal sustainability had they been introduced in 1980 .

\section{Eurobonds II}

The German re-unification caused a spike in the stock of debt and consequently on interest rates. Therefore, the German interest rate in 2010 is considered to be unaffected from any effects of the reunification and is used for the whole sample periods, which modified the model in equation (9) to:

$$
G_{t}^{r *}=G_{t}+r_{\text {German } 2010} \text { Blue Bonds }_{t}+r_{\text {rit }} \text { Red Debt }_{t-1}
$$

\section{Eurobonds III}

Lastly, the Italian interest rate in 2010 is also used for the $r_{\text {rit }}$ to check if it significantly alters the results obtained in equation (10). Consequently, the following is estimated:

$$
G_{\text {Italian } t}^{r *}=G_{t}+r_{\text {German } 2010} \text { Blue Bonds }_{t}+r_{\text {Italian } 2010} \text { Red Debt }_{t-1}
$$

This estimation enables us to simulate the impact of Eurobonds on fiscal sustainability had they been introduced in 2010 .

Eurobonds and the fiscal sustainability of the Eurozone 
Will the Eurobonds change the fiscal sustainability of the Eurozone as a whole? In order to test this hypothesis, the original model outlined above is used, but the composition of government expenditure inclusive of interest rate payments is changed. The same methods for panel unit roots and co-integration will be used for the three separate estimations of fiscal sustainability using the Eurobonds.

It is expected that national fiscal sustainability will be sensitive to the interest rates used and this will also be relevant for the fiscal sustainability of the whole Eurozone. It is possible that Eurobonds I will not significantly alter the fiscal sustainability of the countries, as historical interest rates have been relatively high and volatile. The spread between German interest rates bond yields and on other countries varies substantially among the countries. ${ }^{8}$

However, it is possible that Eurobonds II and Eurobonds III could ameliorate the countries' fiscal sustainability, as the interest rates will be significantly lower than the historical series used in Eurobonds I. This would bolster the arguments of those favouring the introduction of Eurobonds.

\section{Discussion of the Data and the Empirical Results}

The data-set used covers the period between 1980 and 2010, which is obtained from the OECD National Accounts Database, the Eurostat Database and the IMF IFS Database. The variables are total marketable government debts, total general government expenditure and revenue and interest rates on long term (10 year) government bonds.

\footnotetext{
${ }^{8}$ We have calculated the ratio of spread in interest rates to change in growth. If interest rate on government debt increases faster than economic growth, then a country is become unsustainable. This is similar to the Present Value of Borrowing Constraint, PVBC constraint (Alfonso, 2005). The ratio calculates the average spread of interest rates (on long term government yields) of EMU member countries with that of Germany's. The spread on interest rates on bond yields had substantially decreased at the start of the Euro. The results indicate that the average spread of interest rates with reference to German rate, in 1980-1991 was 57.12\% in 1992-1999 it fell to $29.55 \%$ in 2000 and reached $2.60 \%$ in 2006 . However, it increased again in the last period to $22.28 \%$. It was only Luxembourg that had interest rates lower than Germany between 2000 and 2006.
} 


\section{National Fiscal Sustainability}

Table 1 reports the results on the fiscal sustainability in Europe, which illustrates the imbalances within the monetary union. Only three of the eleven countries examined are strongly sustainable. These are Germany, Austria and Finland. Germany has always been known for being fiscally prudent, and considering how closely dependent Austria's economy is on Germany, the results indicate that it also follows the German fiscal stance. Finland experienced a severe crisis in the 1990s and since then it has kept its public finances in order. On the other hand, most countries appear to be weakly sustainable: France, Netherlands, Ireland, Spain and Portugal. Considering, the impact of the financial crisis and the "catch-up" phase of Ireland, Spain and Portugal it not surprising that they are found to be weakly sustainable. It is somewhat surprising that France and Netherlands are considered weakly sustainable. This could have some serious implications for the EMU as a whole, if France and Germany are to be the main guarantors of the European Financial Stability Facility, EFSF and the Eurobonds (Barber, 2011). Lastly, results for Italy and Belgium indicate that the countries are fiscally unsustainable. This is consistent with the countries' accumulated stock of debt that stands at $109 \%$ and $96 \%$ of their GDP, respectively, in 2010 . The S\&P credit rating for both countries for most of 2010 was "stable". Fiscal sustainability of the countries was not, generally, reflected in their credit ratings. Credit ratings usually take into account more than just government revenues, government expenditure and interest payments when calculating each country's rating. The belief of an implicit guarantee of a bail-out could also have influenced their ratings. Therefore, one would expect the credit ratings of these countries to be worse than what was reported.

Cecchetti et al. (2011) identify government debt in the range of $80 \%-100 \%$ of a country's GDP as being excessively high and would have negative consequences for the economy. 
High debt "raises real volatility, increases financial fragility and reduces average growth" (Cecchetti, et al., 2011). This was implied in the Maastricht Treaty criteria, as policymakers believed that the optimal public debt ratio was $60 \%$ of a country's GDP. This ratio was also believed to be a realistic threshold (Bismut and Jacquet, 1997). According to this view, Italy, Belgium, Portugal and Greece have such high levels of debt. In certain respects, credit rating agencies seemed to have recognised this as three of these countries' credit ratings were reclassified as having "negative" outlooks as at 2011 (Standard and Poor, 2011).

\section{Eurozone Fiscal Sustainability}

An integrated time series is used to evaluate fiscal sustainability at an aggregate level; this could have important repercussions for the Eurozone's ability to counteract any crisis. According to both Kao and Pedroni panel co-integration tests, there is a long run relationship between tax revenues and government expenditure inclusive of interest rate payments for the Eurozone as a whole. Thus it appears that in general, governments of these countries spend beyond their means. However, seeing how the majority of the countries were only weakly sustainable, as reported in Table 1 was not unexpected.

\section{National Fiscal Sustainability Using Eurobonds}

In order to examine how national fiscal sustainability changes when countries debt is converted to "blue bonds" and "red debt", three different tests were performed. First, using the German historic rate of interest; secondly, using the German rate of interest at 2010, and; thirdly, using the countries' national rate of interest. The results are reported in Table 3. When the German historical interest rate on 10 year bond yields for the "blue bonds" and national historical interest rates for the "red debt" are used, only Finland remains strongly fiscally sustainable while Belgium experiences an improvement in its fiscal sustainability, 
becoming weakly sustainable. The fiscal sustainability of Austria and Spain became worse than what was reported in Table 2. The fiscal sustainability of the remaining countries does not seem to be significantly different from the previous ones.

The results also indicate that using the German interest rate on 10 year bond yields in 2010 for the interest rate on all "blue bonds", has significantly improved the sustainability of France, Italy and Belgium. However, Finland's fiscal sustainability worsens. This could be interpreted as the cost of guaranteeing the debt of more indebted countries like Italy and Belgium. The situation remains the same for national fiscal sustainability for the remaining six countries. The effects are significant, but not substantial. When the German 2010 interest rate is used for "blue bonds", and national 2010 interest rate for "red debt", this leads to a significant change in the fiscal sustainability of all the countries considered. The fiscal sustainability of five countries: France, Italy, Belgium, Netherlands and Ireland along with the rest, apart from Belgium become strongly sustainable. Similar to the previous results, only Finland recorded a decline in its sustainability; becoming weakly sustainable. Hence, Eurobonds III (using 2010 interest rates for "blue bonds" and "red debt") could be a viable solution as they positively and significantly improve the fiscal sustainability of most of the countries.

\section{Fiscal Sustainability for the Whole Euro-Zone Using Eurobonds}

It is evident from the foregoing that the Eurobonds have improved the fiscal sustainability of the countries as they alter the composition of $G_{t}^{r *}$, but the debt is sensitive to the type of interest rates that are used. If one were to use Eurobonds I, the Eurozone would still be considered fiscally unsustainable, as found by both Pedroni and Kao co-integration tests reported in Tables 4 and 5. However, when using Eurobonds II, the Kao test suggests that 
there is co-integration between government expenditure and tax revenues. Nevertheless, the Pedroni tests, fail to reject the null hypothesis of no co-integration.

Lastly, both Kao and Pedroni tests (Table 5) show that there is co-integration between tax revenues and government expenditure inclusive of interest rate payments when using German and national interest rates in 2010 for "blue" bonds and "red debt". Therefore, it appears that the Eurobonds could indeed significantly improve fiscal sustainability of the countries, both at national and at the Eurozone levels.

Table 6 presents the summary of the estimated results. It summarizes the results and classifies the countries' fiscal positions into strongly sustainable, weakly sustainable and unsustainable. Three countries are found to be strongly sustainable based on national analysis. These are Germany, Austria and Finland. Five countries; France, Netherlands, Spain, Ireland and Portugal are weakly sustainable. Italy and Belgium are the only countries that are nationally un-sustainable. ${ }^{9}$ The results almost remained the same when the Eurobonds and the German historic interest rates were used, with the exception that the fiscal position of Austria deteriorated to weakly sustainable. However, when the Eurobonds and the 2010 German's interest rates were used, the fiscal stance of all the countries improved and they have all become sustainable. Even Italy that was found to be un-sustainable in the previous results became strongly sustainable along with France and Netherlands. Overall, the analysis strongly supports the argument for the consolidation of the Euro countries' national debts.

\section{Conclusion, Policy Implementations and Limitation}

The purpose of this paper is to investigate the extent of fiscal sustainability of ten Euro member countries and the whole union as well as evaluating whether or not the suggested

\footnotetext{
${ }^{9}$ The results at the national level are consistent with the ones reported on Italy and Spain by Trachanas and Katrakilidis (2013) who studied fiscal sustainability of Greece, Italy and Spain.
} 
fiscal consolidation of the Euro countries' national debts is a viable, long term solution to the current sovereign debt crisis. It empirically investigated the effects of the Eurobonds on the Euro countries' national debts. The role of the Eurobonds in fiscal sustainability of the countries studied at both national and Euro zone levels is investigated. This is with the aim of finding out if the Eurobonds would give governments of the member countries of the Euro room for manoeuvring to deal with their domestic structural issues and achieve a minimum fiscal sustainability. The results, based on the national data, indicate that only three core countries (Germany, Finland and Austria) showed characteristics of medium term fiscal sustainability. Five countries (Netherlands, France, Spain, Portugal and Ireland) appear to be weakly sustainable, meaning that without a change in their fiscal policy and taking structural actions their positions may deteriorate. Two countries (Italy and Belgium), on the other hand, appear to be structurally unsustainable due to their large accumulated stock of debt. To achieve sustainability, the countries need to take drastic steps to reduce their stock of debt whilst pursuing economic reform for a long-run sustainability. This is more pertinent in the case of Italy as indicated by its debt ratio relative to that of Germany. Constant increase in the stock of debt accompanied by increase in inflation relative to Germany will aggravate the reduction in economic activity ${ }^{10}$. Belgium's economy is closely linked to Germany's economy, but its historic stock of debt is problematic. The results obtained from the estimates that included the Eurobonds found that the fiscal sustainability of the countries, both at individual and Euro levels has substantially improved, but is dependent on the rate of interest rates used.

The framework used in the paper can be applied to studying the fiscal sustainability of nonEuro countries, either at individual or at aggregate levels where the countries participate in a

\footnotetext{
${ }^{10}$ This is discussed in Section 2.
} 
monetary union like those in Euro or otherwise. For example, it can be used to analyse fiscal sustainability of the individual states in the US or to study fiscal sustainability of the US as a whole. Other potential candidates are the CFA zones of West and Central Africa. The analysis, as found in this paper, can shed light on the policy implication of having a monetary union without a fiscal consolidation.

The main limitation of the study is that the framework used only takes into account the relationship between government expenditure, interest rate payments on stock of debt and tax revenue. However, the ageing population in Europe can negatively affect public finances as it poses the threat of an increased burden on pensions and the diminishing growth rate of the labour force. This is the main limitation of the study. This, points to a future research where a model that will address this could be used.

\section{References}

Alfonso, A. (2005) "Fiscal Sustainability: The Unpleasant European Case", FinanzArchiv/Public Finance Analysis, Vol. 61, No. 1, pages 19-44

Arestis, P., Khan, M., \& Luintel, K. B., (2002), Fiscal Deficits in Monetary Unions: A comparison of EMU and United States, Eastern Economic Journal, Volume 28, No. 1, pages 89-103.

Arghyrou, M. G. and Luintel, K. (2007). "Government Solvency: Revisiting some EMU countries”. Journal of Macroeconomics Volume 29, Issue 2, pages 387-410.

Bajo-Rubio, O., Díaz-Roldán, C. \& Esteve, V., (2009) "Deficit sustainability and inflation in EMU: An analysis from the Fiscal Theory of the Price Level," European Journal of Political Economy, Volume 25, Issue 4, pages 525-539, December. 
Banjeree, A, (1999), Panel Data Unit Roots and Cointegration: An Overview, Oxford Bulletin of Economics and Statistics, Volume 61, Issue S1, pp. 607-629 (November).

Barber, T., (2011), Four Steps to fiscal union, Financial Times, 12th August, p.5.

Bénassy-Quéré, A. \& A. Roussellet, G. (2013) "Fiscal Sustainability in the Presence of Systemic banks: the case of EU countries”, International Tax and Public Finance, Article not assigned to an issue.

Bismut, C., \& Jacquet, P., (1997), "Fiscal consolidation in Europe", Tokyo Club Papers, Volume 10, pp. 81 - 154, December.

Cecchetti, S., G., Mohanty, M.S., \& Zampolli, F., (2011), The Real Effects of Debt IN Federal Reserve Bank of Kansas City eds, Jackson Hole, Achieving Maximum LongRun Growth, $25^{\text {th }}-27^{\text {th }}$ August 2011, Wyoming, USA.

Corsetti, G. \& Roubini, N (1991) “Deficits, Public Debt and Government Solvency: Evidence from OECD countries", Journal of Japanese and International Economies, Volume 5, Issue 4, pages 354-380.

De Castro, F. \&. De Cos, P. H. (2002) "On the sustainability of the Spanish public budget performance," Hacienda Pública Española, IEF, Volume 160, Issue 1, pages 9-28.

De Grauwe, P. (2012) "The Governance of a Fragile Eurozone", Australian Economic Review, Volume 45, Issue 3, pages 255 - 268.

Delpla, Jaques; von Weizsäcker, Jakob (2011) "Eurobonds: The blue bond concept and its implications," Bruegel policy contribution, No. 2011/02, pages 01-06.

Hakkio, C.S. and Rush, M., (1991), Is the Budget Deficit "too large?”, Economic Inquiry, Volume 29, Issue 3, pages 429-445, July.

Hamilton, J.D., and Flavin, M.A.,(1986), On the Limitations of Government Borrowing: A Framework for Testing, American Economic Review, Volume 76, No. 4, pages 808819, September. 
Hsiao, C., (2003), Analysis of Panel Data, $2^{\text {nd }}$ Edition. Cambridge: Cambridge University Press, Cambridge, UK, pages 216-217.

Legrenzi, G. \& Costas Milas, (2012) "Nonlinearities and the Sustainability of The Government'S Intertemporal Budget Constraint," Economic Inquiry, Volume 50, Issue 4, pages 988-999.

Maddala, G. S. \& Kim, I. (1999) Unit Roots, Cointegration and Structural Change, Cambridge: Cambridge University Press.

Papadopoulos, A. P., Sidiropoulos, M. G. (1999), “The Sustainability of Fiscal Policies in the European Union”. International Advances in Economic Research, Volume 5, Issue 3, pages 289-307.

Phillips P. C. B. \& Hyungsik R. M. (1999) "Linear Regression Limit Theory for Nonstationary Panel Data”, Econometrica, Vol. 67, No. 5, pages 1057-1111.

Quintos, Carmela E., (1995), Sustainability of the Deficit Process with Structural Shifts, Journal of Business and Economic Statistics, Volume 13, No. 4, pages 409-417, October.

Standard and Poor, (2011), Standard \& Poor, Benchmarks, Research, Data and Analytics. [Online].: http://www.standardandpoors.com/home/en/eu (Accessed on 20.08.3013).

The European Union, European Economic Community and the European Atomic Energy Community, Treaty of Rome aka The Functioning of the European Union, $25^{\text {th }}$ of March 1957.

Trachanas, T. \& Constantinos Katrakilidis, (2013), "Fiscal deficits under financial pressure and insolvency: Evidence for Italy, Greece and Spain”, Journal of Policy Modeling, Volume 35, Issue 5, Pages 730-749. 


\begin{tabular}{|c|c|c|c|c|}
\hline \multicolumn{5}{|c|}{$\begin{array}{c}\text { Table 1 } \\
\text { Fiscal sustainability nationally }\end{array}$} \\
\hline Country & $\mu_{t}$ & $G_{t}^{r}$ & $R^{2}$ & Sustainability \\
\hline Germany & $5.5213^{*}$ & $0.5443^{*}$ & 0.0698 & Strongly sustainable \\
\hline France & -0.8606 & $0.9503 *$ & 0.8438 & Weakly sustainable \\
\hline Italy & -3.069124 & $1.0247 *$ & 0.9503 & Unsustainable \\
\hline Austria & $1.0952 *$ & $0.7882 *$ & 0.9503 & Strongly Sustainable \\
\hline Netherlands & 1.8436 & $0.7431 *$ & 0.7231 & Weakly sustainable \\
\hline Belgium & 2.4882 & $0.6529 *$ & 0.3746 & Unsustainable \\
\hline Finland & $8.7047^{*}$ & 0.1926 & 0.0676 & Strongly Sustainable \\
\hline Spain & $14.8845 * *$ & -0.1625 & 0.0064 & Weakly sustainable \\
\hline Ireland & $15.7370 *$ & -0.4281 & 0.0699 & Weakly sustainable \\
\hline Portugal & 4.0847 & 0.5304* & 0.2863 & Weakly sustainable \\
\hline
\end{tabular}

\begin{tabular}{|c|c|c|c|c|c|c|c|}
\hline \multicolumn{8}{|c|}{$\begin{array}{c}\text { Table 2 } \\
\text { Pedroni Panel Cointegration }\end{array}$} \\
\hline & Panel V & $\begin{array}{c}\text { Panel } \\
\text { Rho }\end{array}$ & Panel PP & Panel ADF & Group Rho & Group PP & Group ADF \\
\hline t-statistic & -1.8180 & 2.5528 & 2.8458 & 2.2053 & 2.6088 & 2.4766 & 1.7617 \\
\hline P-value & 0.9655 & 0.9947 & 0.9978 & 0.9863 & 0.9955 & 0.9934 & 0.9609 \\
\hline \multicolumn{8}{|c|}{ Kao Panel Co-integration } \\
\hline t-statistic & & & & & & & 0.192032 \\
\hline P-value & & & & & & & 0.4239 \\
\hline
\end{tabular}

\begin{tabular}{|l|c|c|c|l|}
\hline \multicolumn{5}{|c|}{ Table 3 } \\
\hline Country & $\mu_{t}$ & $G_{t}^{r}$ & $R^{2}$ & Sustainability \\
\hline France & -3.2225 & $1.1043^{*}$ & 0.7671 & Weakly sustainable \\
\hline Italy & -0.1299 & $0.8413^{*}$ & 0.7158 & Unsustainable \\
\hline Austria & 0.9228 & $0.8007^{*}$ & 0.9167 & Weakly sustainable \\
\hline Netherlands & 1.5107 & $0.7652^{*}$ & 0.6801 & Weakly Sustainable \\
\hline Belgium & 3.5712 & $0.5766^{*}$ & 0.4060 & Weakly sustainable \\
\hline Finland & $9.3281^{*}$ & 0.1431 & 0.0195 & Strongly sustainable \\
\hline Spain & -1.0179 & 0.9473 & 0.0984 & Unsustainable \\
\hline Ireland & $14.6428^{*}$ & -0.3416 & 0.0259 & Weakly sustainable \\
\hline Portugal & -1.8561 & $1.0000^{*}$ & 0.6594 & Weakly sustainable \\
\hline \multicolumn{5}{|c|}{ Eurobonds with German and national interest rates at 2010 values } \\
\hline Country & $\mu_{t}$ & $G_{t}^{r}$ & $R^{2}$ & Sustainability \\
\hline France & $4.3772^{*}$ & $0.6188^{*}$ & 0.9800 & Strongly sustainable \\
\hline Italy & $2.1188^{*}$ & $0.7213^{*}$ & 0.9819 & Strongly sustainable \\
\hline Austria & $3.6414^{*}$ & $0.6154^{*}$ & 0.9956 & Strongly sustainable \\
\hline Netherlands & $3.3875^{*}$ & $0.6587^{*}$ & 0.9406 & Strongly sustainable \\
\hline Belgium & $3.5830^{*}$ & $0.5957^{*}$ & 0.8675 & Weakly sustainable \\
\hline Finland & $3.7556^{*}$ & $0.6035^{*}$ & 0.5467 & Weakly sustainable \\
\hline Spain & -2.0996 & $1.0499^{*}$ & 0.6984 & Weakly sustainable \\
\hline Ireland & -1.0373 & $0.9684^{*}$ & 0.4669 & Strongly sustainable \\
\hline Portugal & $3.5004^{*}$ & $0.5946^{*}$ & 0.8686 & Weakly sustainable \\
\hline $\begin{array}{l}\text { Source: OECD data and IMF IFS data } \\
\text { *Significant at 5\% }\end{array}$ (Some variables may not be significant due to lack of data $)$ \\
\hline
\end{tabular}




\begin{tabular}{|c|c|c|c|}
\hline \multicolumn{4}{|c|}{ Table 4 } \\
\hline & Eurobonds I & Eurobonds II & Eurobonds III \\
\hline t-statistic & 0.691331 & -2.2509 & -2.769669 \\
\hline P-value & 0.2447 & $0.0122^{*}$ & $0.0028^{*}$ \\
\hline
\end{tabular}

\begin{tabular}{|c|c|c|c|c|c|c|c|}
\hline \multicolumn{7}{|c|}{ Table 5 } \\
& Panel V & $\begin{array}{c}\text { Panel } \\
\text { Rho }\end{array}$ & Panel PP & Panel ADF & $\begin{array}{c}\text { Group } \\
\text { Rho }\end{array}$ & Group PP & $\begin{array}{c}\text { Group } \\
\text { ADF }\end{array}$ \\
\hline t-statistic & -1.6806 & 2.0967 & 2.3042 & 2.0967 & 2.7437 & 2.9219 & 3.0775 \\
\hline P-value & 0.9536 & 0.9820 & 0.9894 & 0.9820 & 0.9970 & 0.9983 & 0.9990 \\
\hline \multicolumn{7}{|c|}{ Eurobond II Pedroni Panel Cointegration } \\
\hline t-statistic & 0.4322 & 0.4457 & 0.3808 & -1.0349 & 1.6188 & 1.7761 & 0.6254 \\
\hline P-value & 0.3328 & 0.6721 & 0.6483 & 0.1504 & 0.9473 & 0.9621 & 0.2659 \\
\hline \multicolumn{7}{|c|}{ Eurobond III Pedroni Panel Cointegration } \\
\hline t-statistic & 4.0955 & -1.2003 & -0.0824 & $-2.3924^{*}$ & 1.5542 & 1.8124 & $-1.7527^{*}$ \\
\hline P-value & $0.0000^{*}$ & 0.1150 & 0.4672 & 0.0084 & 0.9399 & 0.9650 & 0.0398 \\
\hline
\end{tabular}

\begin{tabular}{|c|c|c|}
\hline \multicolumn{3}{|c|}{$\begin{array}{c}\text { Table } 6 \\
\text { Fiscal Sustainability: Summary }\end{array}$} \\
\hline \multicolumn{3}{|c|}{ Nationally } \\
\hline Strongly Sustainable & Weakly Sustainable & Unsustainable \\
\hline Germany & France & Italy \\
\hline Austria & Netherlands & Belgium \\
\hline \multirow[t]{3}{*}{ Finland } & Spain & \\
\hline & Ireland & \\
\hline & Portugal & \\
\hline \multicolumn{3}{|c|}{ Eurobonds with German Historic Interest Rates } \\
\hline Strongly Sustainable & Weakly Sustainable & Unsustainable \\
\hline \multirow[t]{6}{*}{ Finland } & France & Italy \\
\hline & Austria & Spain \\
\hline & Netherlands & \\
\hline & Belgium & \\
\hline & Ireland & \\
\hline & Portugal & \\
\hline \multicolumn{3}{|c|}{ Eurobonds with German and National Interest Rates at 2010} \\
\hline Strongly Sustainable & Weakly Sustainable & Unsustainable \\
\hline France & Belgium & \\
\hline Italy & Finland & \\
\hline Austria & Spain & \\
\hline \multirow[t]{2}{*}{ Netherlands } & Ireland & \\
\hline & Portugal & \\
\hline
\end{tabular}

